\title{
FOURTH SPECIES OF DUCKEELLA (ORCHIDACEAE) DISCOVERED IN COLOMBIA
}

\author{
Marta Kolanowska $^{1}$ \& Dariusz L. SzlachetKo
}

\begin{abstract}
Duckeella humboldtii, a new species from Colombia, is described, illustrated and placed within the key for determination of Duckeella Porto \& Brade representatives. The comparative morphology of all known species of the genus is presented.
\end{abstract}

Key words: biodiversity, Neotropics, savanna, taxonomy

Marta Kolanowska \& Dariusz L. Szlachetko, Department of Plant Taxonomy and Nature Conservation, University of Gdańsk, Wita Stwosza 59, 80-308 Gdańsk, Poland; e-mail: martakolanowska@wp.pl

\section{INTRODUCTION}

The classification of the primitive orchids traditionally placed in the subtribe Pogoniinae is still discussed among taxonomists, mainly due to the relatively numerous plesiomorphic characters observed in the group and the lack of apomorphic characters. This subtribe usually includes Cleistes Rich. ex Lindl., Duckeella Porto \& Brade, Isotria Raf., Pogonia Juss. and Pogoniopsis Rchb. f., representatives of which are found mostly on both American continents as well as in East Asia. Recently an additional genus, Cleistesiopsis Pansarin \& Barros, has been segregated from Cleistes (Pansarin \& de Barros 2008). Clear assignment of the subtribe to a higher taxon has been problematic; Dressler (1993) decided to list it as a group of uncertain taxonomic affinity, without trying to classify its genera among other orchids despite his earlier concept of placing them in Vanilleae (Dressler 1981). Based primarily on gynostemium morphology, Szlachetko (1995) included Pogoniinae in the tribe Arethuseae (Vanilloideae), at the same time recognizing Duckeella as sole member of a newly created subtribe. Recent molecular studies indicated that Duckeella is sister to all other genera traditionally placed in Pogoniinae (Cameron \& Chase 1999; Pansarin et al. 2008).

\footnotetext{
1 Corresponding author
}

Representatives of Duckeella produce elongate, fibrous, hairy roots, and basal, coriaceous, linear leaves. Their resupinate yellow flowers are arranged in a terminal simple or branched raceme. The spreading tepals are free and the sepals and petals are similar in shape and size. The petaloid lip is constricted in the basal part, the lateral (basal) lobes are inconspicuous, and the middle lobe is essentially larger, more or less ligulate. The lip disc is ornamented in the basal part with a crested callus. The gynostemium characters distinguishing Duckeella from other vanilloid orchids specified by Szlachetko (1995) include the presence of a broadly winged gynostemium and two wing-like apical projections on both sides of the anther, the lack of a viscidium, the motile, incumbent anther, and granular pollinia.

Although the genus was described over 70 years ago (Porto \& Brade 1940), so far only three species of Duckeella have been recognized, the last over 50 years ago (Schweinfurth 1961). Two species, D. adolphii Porto \& Brade and D. pauciflora Garay, are known from the Orinoco and Amazon lowlands of Colombia, Venezuela and Brazil, where they were found at elevations up to $c a 175 \mathrm{~m}$ a.s.l. The third species, D. alticola C. Schweinf., is considered endemic to southeastern Venezuela where it grows 
at $1350-2000 \mathrm{~m}$ a.s.1. on the perpetually wet summits of tepuis (Cameron 2003).

All three species were reported from Colombia by Ortiz Valdivieso and Uribe Vélez (2007) but the authors did not provide any reference material and we did not find any herbarium specimen of D. alticola collected in that country.

During an examination of the orchid material deposited in the Colombian herbarium of the Alexander von Humboldt Institute (FMB) we came across a distinctive species of Duckeella which is described here as new and placed in the key to identification of representatives of the genus.

\section{DESCRIPTION OF NEW SPECIES}

Duckeella humboldtii Kolan. \& Szlach., sp. nov. Fig. 1

Species similar to Duckeella adolphii Porto \& Brade but distinguished by having oblong-obovate, acute petals, obliquely ovate lip lateral lobes, and an apically digitate lip callus.

HolotyPe: COLOMBIA. Dept. Vichada: Cumaribo, Corregimiento de Santa Rita. A $2 \mathrm{~km}$ al S del centro Administrativo del parque, cerca del sitio conocido localmente como cerro Tomás, 200 m, 2 Feb. 2004, H. Mendoza \& A. Robles 15504 (FMB).

Paratype: COLOMBIA. Dept. Vichada: Cumaribo, Corregimiento de Santa Rita. A $2 \mathrm{~km}$ al S del centro Administrativo del parque, cerca del sitio conocido localmente como cerro Tomás. Sabanas de relieve plano y plano-cóncavo, 200 m, 2 Feb. 2004, H. Mendoza \& A. Robles 15452 (FMB).

Plant up to $35 \mathrm{~cm}$ tall. Stem slender, erect. Leaves basal, up to $25 \mathrm{~cm}$ long, $0.6-0.7 \mathrm{~cm}$ wide, linear, acute. Inflorescence up to $3.5 \mathrm{~cm}$ long, successively few-flowered. Floral bracts ca $6 \mathrm{~mm}$ long, ovate-lanceolate, acute. Ovary 10-15 mm long. Flowers yellow. Dorsal sepal $20 \mathrm{~mm}$ long, $5 \mathrm{~mm}$ wide, narrowly ovate, subacute, 5-veined. Lateral sepals $21 \mathrm{~mm}$ long, $6 \mathrm{~mm}$ wide, oblongelliptic, subacute, 7-veined. Petals $20 \mathrm{~mm}$ long, $6 \mathrm{~mm}$ wide, somewhat falcate, oblong-obovate, acute, 7-veined. Lip $19 \mathrm{~mm}$ long, $5 \mathrm{~mm}$ wide, constricted in the basal quarter; lateral lobes obliquely ovate, subobtuse; middle lobe oblong-elliptic, obtuse, 9-veined; basal callus prominent, about $3.5 \mathrm{~mm}$ long, longitudinally grooved, apically digitate. Gynostemium short, $c a 7 \mathrm{~mm}$ long.

Eтymology. To honor Alexander von Humboldt (1769-1859), whose botanical studies in Latin America (1799-1804) constituted the basis for its phytogeography.

Distribution AND ECOLOGY. The new species is known exclusively from eastern Colombia. Duckeella humboldtii grows in humid savanna at $c a$ $200 \mathrm{~m}$ a.s.1. It was found flowering in February. Apparently this species grow sympatrically with D. adolphii (J. L. Zarucchi \& C. E. Barbosa 3586, FMB).

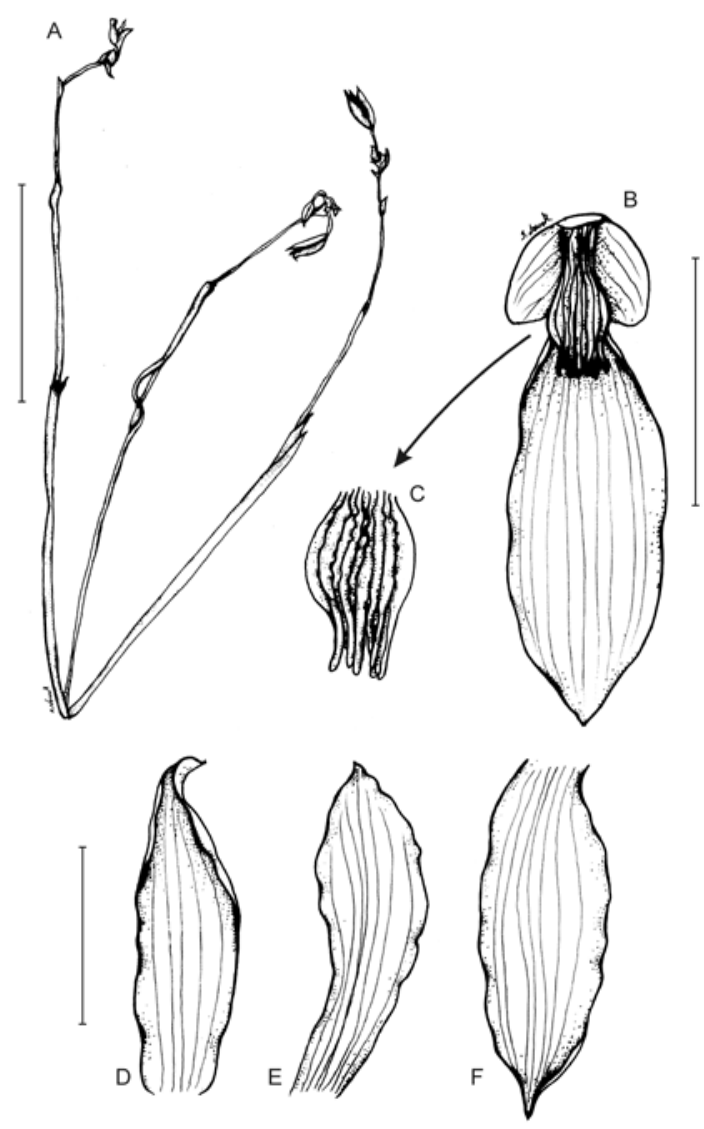

Fig. 1. Duckeella humboldtii Kolan. \& Szlach., sp. nov. A habit, B - lip, C - details of callus, D - dorsal sepal, E - petal, F - lateral sepal (drawn by S. Nowak from holotype). Scale bars: $A=10 \mathrm{~cm}, \mathrm{~B}-\mathrm{F}=10 \mathrm{~mm}$. 
Notes. The new species resembles D. adolphii known from Colombia, Venezuela and Brazil, from which it is easily distinguished by its lip and petal morphology. The petals of the new entity are oblong-obovate and acute. In other species of the genus the petals are usually ovate-lanceolate, and most often obtuse, rarely subacute. In most species of Duckeella the lip lateral lobes are auriculate-rounded. In $D$. humboldtii the lip lateral lobes are obliquely ovate. One of the most important diagnostic features used in discrimination of Duckeella species is the form and lobation of the lip callus. It is usually composed of lamellae of various width and height, with digitate or fimbriate apical parts. The lip callus of the new species is digitate in the apical part. In closely related D. adolphii the lip callus is comprised of apically fimbriate lamellae.

\section{Key to the SPECIES OF DUCKEELLA}

1. Petals distinctly wider than sepals, broadly rhombicovate to elliptic-ovate ............... 2

1. Petals subequal or slightly wider than sepals, oblongobovate to ovate-lanceolate ............ 3

2. Lip middle lobe oblong-obovate to ligulate-obovate, apex rounded ...... D. pauciflora Garay

2. Lip middle lobe oblong, apex truncate ........ ............... D. alticola C. Schweinf.

3. Lip lateral lobes auriculate-rounded, apical part of callus fimbriate ...... D. adolphii Porto \& Brade

3. Lip lateral lobes obliquely ovate, apical part of callus digitate ....... D. humboldtii Kolan. \& Szlach.

ACKNOWLEDGEMENTs. We are grateful to the Curator and staff of FMB for their kind hospitality and assistance during our visit, Sławomir Nowak for preparing the illustration, and the anonymous reviewer for valuable comments on the manuscript.

\section{REFERENCES}

Cameron K. M. 2003. Duckeella. In: A. M. Pridgeon, P. J. Cribb, M. W. Chase \& F. N. Rasmussen (eds), Genera Orchidacearum. 3: 289-291. Oxford University Press, Oxford.

Cameron K. M. \& Chase M. W. 1999. Phylogenetic relationships of Pogoniinae (Vanilloideae, Orchidaceae): an herbaceous example of the eastern North America - eastern Asia phytogeographic disjunction. J. Pl. Res. 112: 317-329.

DreSSLER R. L. 1981. The Orchids: Natural History and Classification. Harvard University Press, Harvard.

Dressler R. L. 1993. Phylogeny and classification of the orchid family. Dioscorides Press, Portland.

Ortiz Valdivieso P. \& Uribe Vélez C. 2007. Galería de Orquideas de Colombia (CD edition). Asociación Bogotana de Orquideología, Bogotá.

Pansarin E. R. \& DE Barros F. 2008. Taxonomic notes on Pogonieae (Orchidaceae): Cleistesiopsis, a new genus segregated from Cleistes, and description of two new South American species, Cleistes batistana and C. elongata. Kew Bull. 63(3): 441-448.

Pansarin E. R., Salatino A. \& Salatino M. L. F. 2008. Phylogeny of South American Pogonieae (Orchidaceae, Vanilloideae) based on sequences of nuclear ribosomal (ITS) and chloroplast ( $p s a B, r b c L, r p s 16$, and $\operatorname{trnL}-F$ ) DNA, with emphasis on Cleistes and discussion of biogeographic implications. Organisms Diversity \& Evolution 8(3): 171-181.

Porto P. \& Brade A. C. 1940. Orchidaceae Novae Brasiliensis III. Anais Reunião Sul-Amer. Bot. 3(1): 31-43.

SchweInfurth C. 1961. Novelties in the Orchid Flora of the Guyana Highlands I. Bot. Mus. Leafl. 19: 195-214.

SzlachetKo D. L. 1995. Systema Orchidalium. Fragm. Florist. Geobot. Suppl. 3: 1-152. 